\section{An Analysis of Pre-service Elementary School Teachers' Skills in Geometrical Drawing Using Isometric Paper}

Veli Toptas ${ }^{\mathrm{a},}{ }^{,}$, Elif Tugçe Karaca ${ }^{a}$

\author{
Received: 2 September 2017 \\ Revised: 10 October 2017 \\ Accepted: 18 October 2017 \\ ISSN: 1307-9298 \\ Copyright () IEJEE \\ www.iejee.com
}

DOI: 10.26822/iejee.2017236126

\title{
Abstract
}

The aim of this study was to determine pre-service elementary school teachers' capabilities of deciding the viewpoint and perspective in geometrical drawing. The study examined geometrical drawings the participants did on isometric paper. This is a case study, a qualitative study method, and the study data were analyzed using written documents. The study sample included 34 senior students in the Education Faculty's Elementary School Teaching Program at a Turkish public university. They were selected from approximately 205 pre-service teachers. The students participated in the study on a voluntary basis. The study results revealed that the pre-service teachers generally had weak skills in geometrical drawing. The participants had better skills in building structures which they saw from the air using unit blocks, and forming a structure of which they had the direct views (left and right; front and back) using unit blocks. However, the participants had weaker skills in drawing the direct views of the structures they had built, recognizing the connections between the left-right views and front-back views of the structures and drawing the structures they built on isometric paper in perspective.

Keywords: Drawing skills, geometry, Isometric paper, pre-service primary school teacher, mathematics teaching.

\section{Introduction}

It has been suggested that the introduction to geometrical figures and naming, building, drawing, comparing and classifying them should be highlighted in the early years of primary education. This will also make a positive contribution to students' learning to analyze the shapes of the objects around them and recognize, name and draw their geometrical forms (Ministry of National Education, 2005).

According to the standards of the National Council of Teachers of Mathematics (NTCM, 2000), a mathematics curriculum should include the study of one, two and threedimensional figures in a variety of situations so that the students will be able to determine, describe, compare and classify geometrical figures. Students learn about the geometrical figures by building, drawing, measuring, visualizing comparing, reshaping and classifying them. They also discover the correlations between them and develop their spatial intuition (Powel, 1997).

Geometrical drawing is a sub-field of mathematics, and its version in the elementary mathematics curriculum (MNE, 2009) includes activities that can help students develop spatial reasoning skills. Spatial reasoning is the depiction and understanding of the imaginary movements of twoand three-dimensional objects in space (Clements \& Battista, 1992). According to NCTM (2000), school mathematics is supposed to improve students' spatial reasoning skills in order for them to comprehend space. The development of skills such as understanding space and drawing it, producing models of space and modifying them, and landscaping are based on geometrical thought. Individuals who have spatial reasoning skills are able to observe things in a more meaningful way and solve mathematical problems in daily life more easily (Duatepe \& Paksu, 2013).

Geometrical drawing skill is important in teaching, learning and in the assessment of students' learning. An analysis of mathematics curricula indicate that both primary and elementary curricula include learning acquisitions in building three-dimensional structures using twodimensional views and drawing three-dimensional views on isometric papers using perspective.

Moreover, NCTM standards stress the importance of the development of geometrical thinking and the drawing skills in the process of geometry teaching. Elementary school teaching programs' curricula in education faculties give importance to pre-service teachers' levels of threedimensional thinking and drawing for both mathematics lessons and improving students' spatial thinking skills. However, the curricula do not include a course that focuses on these skills.

Since drawing is not about perception but representation, Piaget and Inhelder claimed that inaccurate drawings indicate the lack of mental tools that are required for spatial representation. Holloway (1967) said that a viewpoint and changes required by that viewpoint were necessary for an object to be represented in perspective by means of mental image or drawing (Toptaş, 2007).

\footnotetext{
a,* Corresponding author: Veli TOPTAŞ, Kirikkale University, Faculty of Education Department of Elementary Education, Kirikkale/Turkey. E-mail: vtoptas@gmail.com

${ }^{\text {b } K i r i k a l e ~ U n i v e r s i t y, ~ F a c u l t y ~ o f ~ E d u c a t i o n, ~ D e p a r t m e n t ~ o f ~ E l e m e n t a r y ~ E d u c a t i o n, ~ K i r i k k a l e / T u r k e y . ~ E-m a i l: ~ t u g c e k a r a c a 85 @ g m a i l . c o m ~}$ 
Mitchelmore $(1976,1980)$ described children's drawings of spatial figures in four main stages. In the first stage, which is the schematic plane stage, drawings are twodimensional or show only one face implying that the child looks at one face of the object in an orthogonal way. The second stage includes the schemas of concrete objects, and at this stage, children are able to draw pictures which can depict many faces, the seen and unseen faces of concrete objects, and they can draw pictures which can or cannot represent their depths. The third stage is the prerealistic stage, which only includes drawings not having a clear or appropriate perspective of visual faces and depth. The fourth stage is the realistic stage, which involves drawing parallel lines at the correct lengths to depict parallelism and depth (Toptaş, 2007).

According to Hoffer (1981), drawing is one of the basic skills which should be taught to students in geometry. Hoffer claims that teaching drawing in geometry helps students to convey their thoughts using shapes. According to Piaget and Inhelder (1957), the unchanging qualities of geometrical shapes, the differences between shape-object relationships or Euclidian geometry depends on the relationships between different shapes or objects. The former is included in a particular shape and the latter covers the projective relations between shapes and objects or the Euclidian relationships among each other. Piaget and Inhelder assert that this type of a global coordination is a main necessity for the creation of a simple shapeobject relationship from children's perspective. In the creation of this type of object-shape relationships which seem to be complicated, a single viewpoint is not formed separately but through the formation of a holistic system connection combined with other compulsory viewpoints.

Distinguishing three-dimensionality requires the use of perspective. According to Piaget (1970) and Morss (1987), the recognition and development of perspective is a great achievement. The representation of perspective requires a conscious coordination between the object and the subject. In other words, it is required to be known that object, subject and the observer are in the same plane depending on the viewpoint (Piaget and Inhelder, 1967). Children understand that objects look different from different perspectives when they are seven years-old, yet they cannot draw or imagine these changes in their viewpoints (Holloway, 1967). They can only understand how an object looks from a specific viewpoint when they see picture drawn from a particular viewpoint in perspective (Holloway, 1967). Children start to be able apply the rules of perspective systematically when they are eight or nine (cited by Authors, 2007).

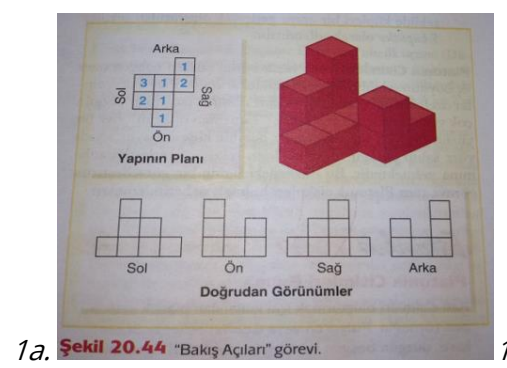

It has been reported that children develop their geometrical thinking by discovering geometrical objects through physical contact, that they create perspective by drawing figures, and that touching objects had a positive effect on their spatial skills in mental rotation and spatial visualization (Clements \& Battista, 1992; Werthessen, 1999).

For all these reasons, it is important that pre-service teachers' skills of perspective, viewpoint and drawing are determined and analyzed. Thus, this study aimed to determine pre-service teachers' ability levels in using perspective in geometrical drawing.

\section{Methodology}

This is a case study, a qualitative study method, including the analysis of written documents. Document analysis can either be a research method itself or used as a supplementary information source when other qualitative methods are used (Yildirim \& Simsek, 2011).

\section{Participants}

The participants of the study included 34 senior students in the Education Faculty's Elementary School Teaching Program in a mid-Anatolian University. As the design of the research is a case study, the participants were selected with convenience sampling method from 105 students in the program on a voluntary basis. 29 of the participants were female and 5 of them were male. The researcher also attended the participants' Mathematics Teaching 1 and 2 courses.

\section{Instruments}

The study examined the participants' skills in geometrical drawing using isometric paper. For this purpose two tasks entitled "Viewpoints" and "Perspective drawing" was used. The tasks were taken from "Geometrical thinking and concepts" chapter of Elementary and Middle School Mathematics: Teaching Developmentally Elementary and Middle School Mathematics by Van de Walle, Karp and BayWilliams (2009). Students who enrolled the study took Mathematics Teaching Course-I and Mathematics Teaching Course-II. In those courses, Elementary and Middle School Mathematics: Teaching Developmentally Elementary and Middle School Mathematics by Van de Walle, Karp and BayWilliams (2009) book was studied during the semesters. Also those tasks are appropriate for the participants' content knowledge level as they had been taught about 3D constructing and drawing 2D forms with isometric papers.

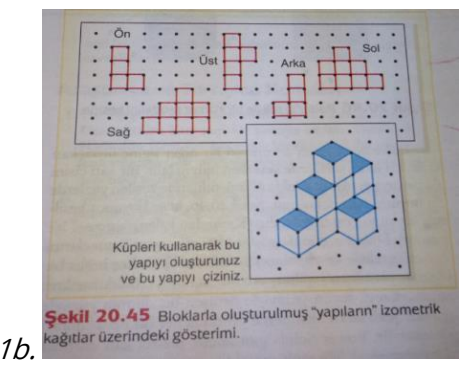

Figure 1. The activities used as data collection tools 


\section{Procedure}

In the first task, identifying a visualization task, one consideration is the degree of the attention that must be given to the particular properties of shapes. One of the main goals of the visualization strand is to be able to identify and draw two-dimensional images of threedimensional figures and to build three-dimensional figures from two-dimensional images. Thus, the pre-service teachers were asked to draw the viewpoints and perspectival drawings shown in the figure. In the activity shown in Figure $1 \mathrm{a}$, the students started by building a structure. The diagram of the structure shows an aerial view of it and the number of blocks in each position. Using this diagram, the students were asked to build the structure and draw views of its left, right, back and front faces.

In the perspectival drawing activity, the students were given a diagram that showed five direct views. Then, they were asked to build a structure according to this diagram. Participants began with an isometric 3D drawing of a building. From the drawing, participants were asked to build the actual building with their unit cubes. To record the result, they were required to draw a plan (top view) indicating the number of blocks in each position. After they built it, they were asked to draw the view of the right-front perspective. The two tasks were completed by the students about 45 minutes.

The authors used the textbook to analyze the participants' drawings and examine their geometrical drawing skills. The participants' ability levels in depicting geometrical viewpoints and perspective were analyzed regarding their geometrical drawing skills. With document analysis techniques the researchers first created a rubric for each task and used giving frequency and percentages about each task and sub-questions in each task.

\section{Results}

The authors interpreted the findings from these activities using frequencies and percentage tables.

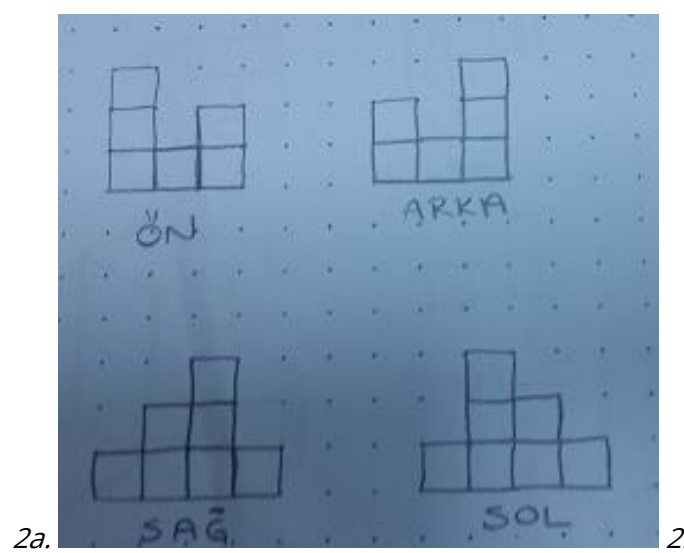

Table 1. Pre-service Teachers'Ability to Build The Structure With Unit Blocks

\begin{tabular}{lcc}
\hline Ability to build the structure & f & $\%$ \\
\hline Able to build the structure & 32 & 94 \\
Unable to build the structure & 2 & 6 \\
\hline Total & 34 & 100 \\
\hline
\end{tabular}

Table 1 presents the findings about participants' ability to build a structure with unit blocks using an aerial view diagram. Of the participants, $94 \%$ were able to build the structure correctly using unit blocks. Of the participants, only $6 \%$, or two participants, were unable to build the structure using the diagram. These findings indicated that pre-service teachers were highly capable of building a structure using unit blocks according to a given plan, and they were generally successful at this activity.

Table 2. Pre-service teachers' ability to draw the views of the structure they built

\begin{tabular}{lcc}
\hline Views & f & \% \\
\hline Front & 15 & 44 drew it correctly \\
Back & 13 & 38 drew it correctly \\
Left & 12 & 35 drew it correctly \\
Right & 10 & 29 drew it correctly \\
\hline
\end{tabular}

Table 2 presents the findings about the participants' ability to draw views of the structure they built with unit blocks on isometric paper. The findings indicate that the participants' ability to draw views of the right, left, back and front faces of the structure was below $50 \%$ in general. The frontal view of the structure was drawn most successfully by $44 \%$ of the students. The least successful view of the structure was from the right with a failure rate of $71 \%$. The achievement rates of the participants in drawing the structure from the back and left were $38 \%$ and $35 \%$. In general, the participants' ability to draw the structures they built from a direct view was below 50\%, which was lower than expected. Samples of correct drawings by the participants were shown in Figure 2, and samples of incorrect drawings are shown in Figure 3.

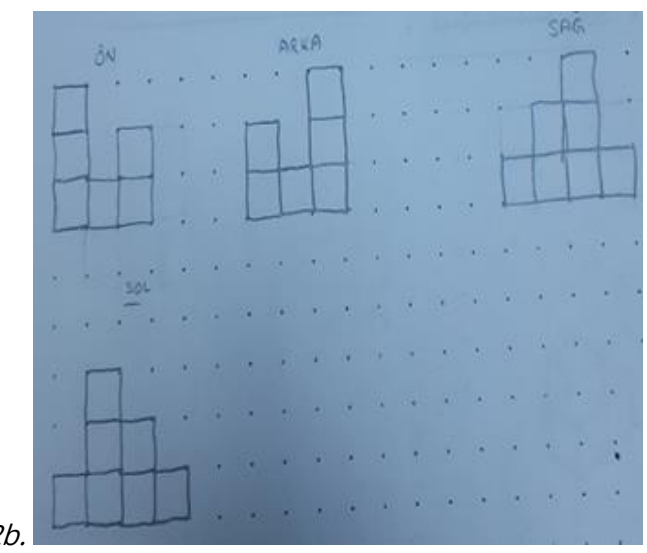

Figure 2. Samples of correct drawings by the participants 

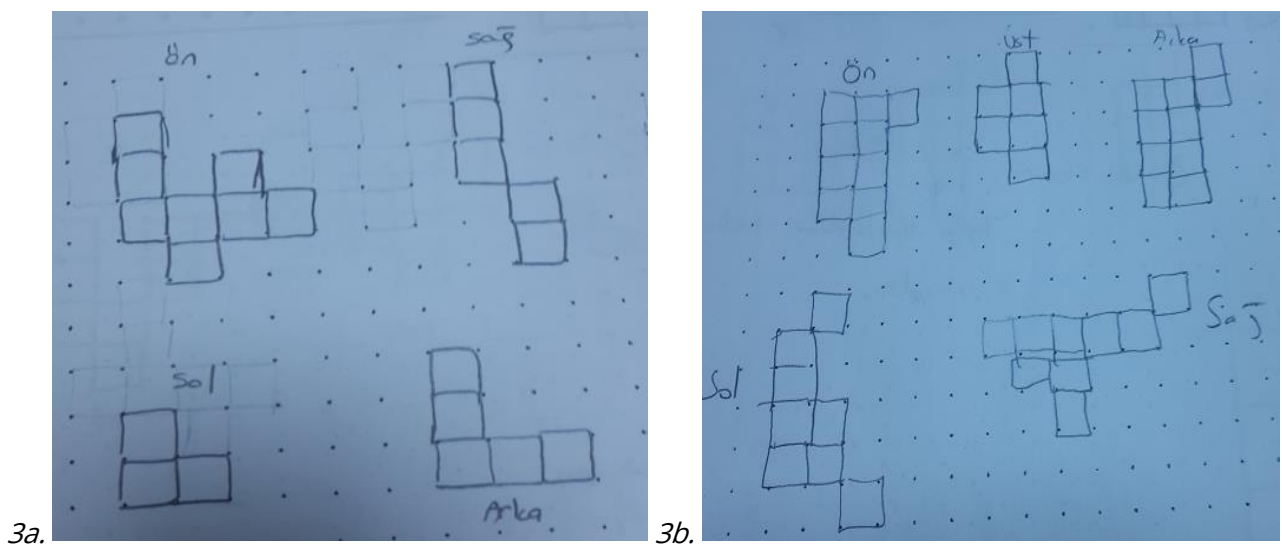

Figure 3. Samples of incorrect drawings by the participants

Table 3. The participants' recognition of the symmetry between the left and right and the frontal and rear views of the structure

\begin{tabular}{lcc}
\hline Symmetry & $\mathrm{f}$ & $\%$ \\
\hline Recognized the symmetry between the views & 12 & 35 \\
$\begin{array}{l}\text { Did not recognize the symmetry between the } \\
\text { views }\end{array}$ & 22 & 65 \\
\hline Total & 34 & 100 \\
\hline
\end{tabular}

Table 3 presents findings about the participants' ability to recognize the symmetry between the right and left and the frontal and rear views of the structure in the viewpoints activity. Table 3 indicates that 35\% of the participants were able to recognize the symmetry between the left and right and the frontal and rear views, while $65 \%$ were unable to do so. The participants' level of recognizing the symmetry was low.

Table 4. The participants' ability to build a structure with unit blocks using left, right, frontal and rear views of it

\begin{tabular}{lcc}
\hline Building the structure & f & $\%$ \\
\hline Able to build the structure with unit blocks & 27 & 79 \\
$\begin{array}{l}\text { Unable to build the structure using unit } \\
\text { blocks }\end{array}$ & 7 & 21 \\
\hline Total & 34 & 100 \\
\hline
\end{tabular}

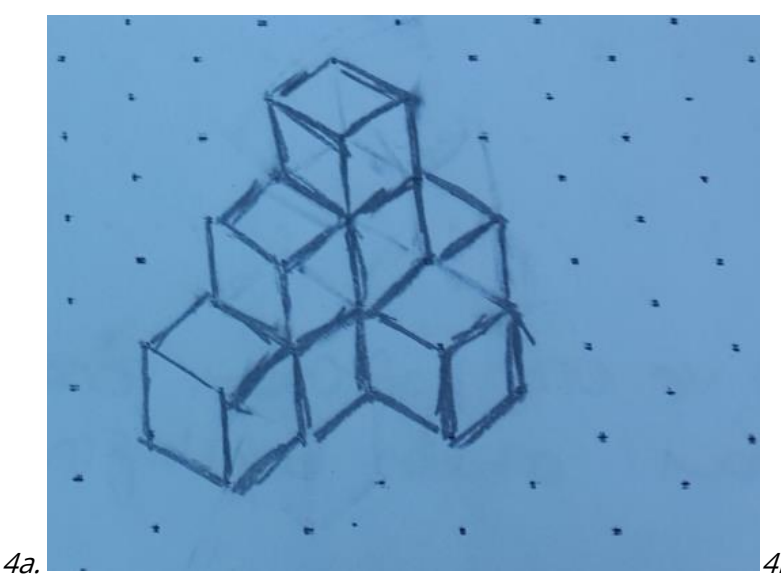

Table 4 presents findings about participants' ability to build a structure with unit blocks using left, right, frontal and rear views of it. The participants were asked to draw four views of structures they built using unit blocks for Table 2, and they were asked to do the reverse for Table 4. Table 4 indicates that $79 \%$ of the participants were able to build the structure with unit blocks using left, right, frontal and rear views of it. Only $21 \%$ of the participants were unable to build the structure, and participants were more successful at building the structure with unit blocks using four views of it.

Table 5. The participants' ability to draw a front right view of the structure they built with unit blocks on isometric paper

\begin{tabular}{lll}
\hline Drawing ability & $\mathbf{f}$ & $\%$ \\
\hline Could not draw it at all & 15 & 44 \\
Drew it incorrectly & 8 & 24 \\
Drew it correctly & 11 & 32 \\
\hline Total & 34 & 100 \\
\hline
\end{tabular}

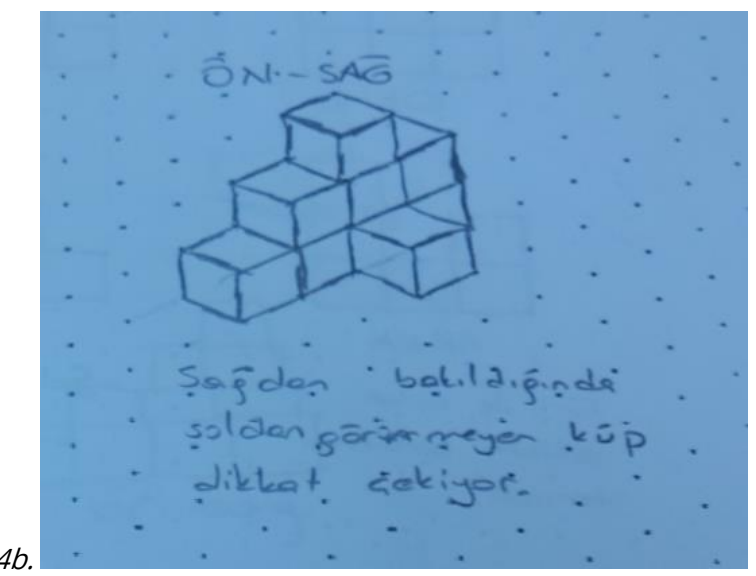

Figure 4. Sample correct drawings of front-right view of the structure 

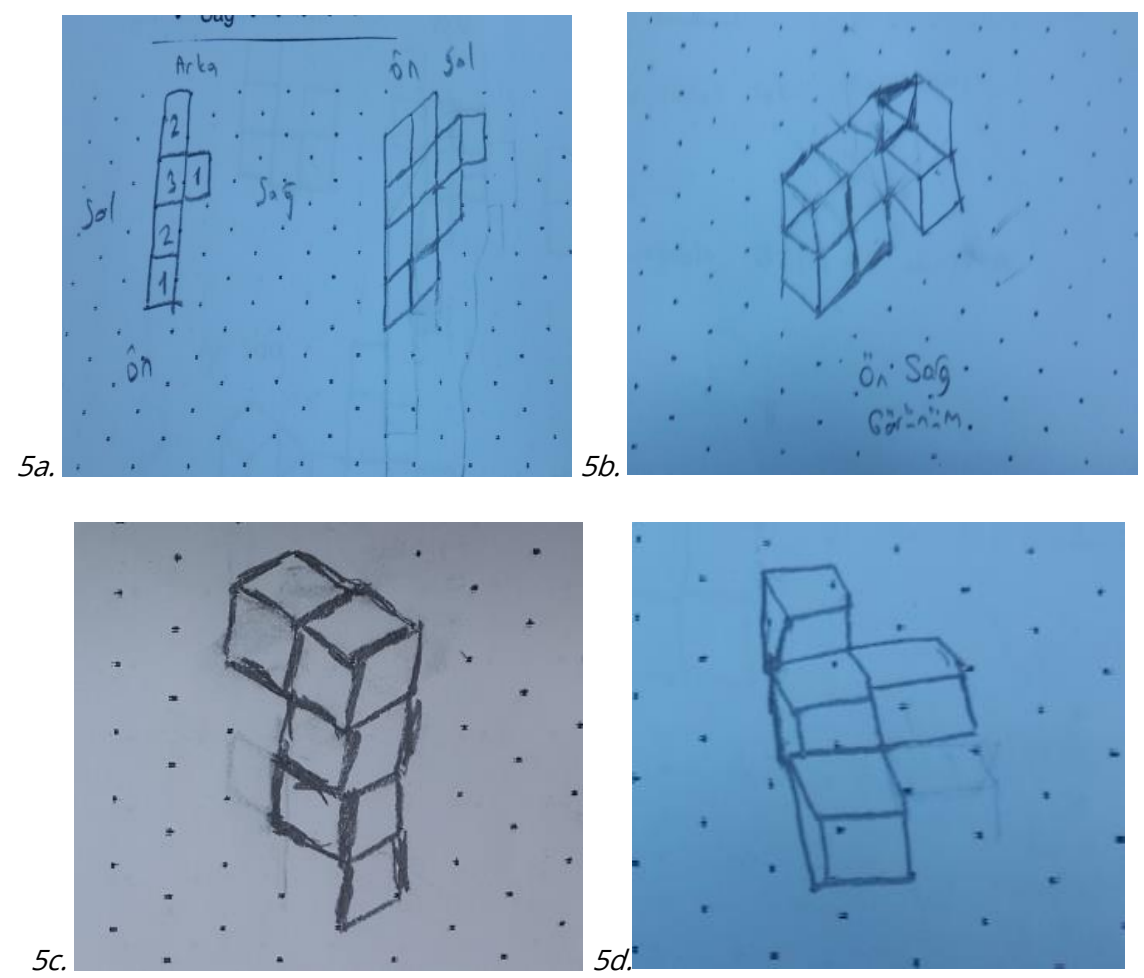

Figure 5. Sample incorrect drawings of the front right view of the structure

\section{Discussion}

The geometry sub-field in the mathematics curricula of the first, second, third, fourth and fifth grades) includes learning acquisitions about building three-dimensional structures using unit blocks and drawing them on isometric paper. Students will be able to learn these things by doing activities in classrooms, and homeroom teachers play an important role in teaching these skills to students. For this reason, it is important to know the level of preservice teachers' skills. This study's results reveal that preservice teachers' skills in this area are not at the expected level.

The first research question asked the participants to build a structure with unit blocks using an aerial view diagram of it. In general, the participants were successful. The participants were not equally successful at geometrical viewpoint and drawing skills. Less than $50 \%$ of the participants succeeded in drawing the front, back, right and left view of the structure. They were most successful at drawing the front view (44\%) and least successful at drawing the view from the right (71\%). This finding indicates that the participants' ability to depict geometrical viewpoints is not at the desired level.

The right and left and the frontal and rear views of the structures built with unit blocks were symmetrical. Of the participants, $35 \%$ recognized this, and $65 \%$ did not. This level of recognition is lower than expected. Considering that there were learning acquisitions about the symmetrical connections between structures and symmetry in the second year mathematics curriculum of the NME, it is a subject of discussion how pre-service teachers will be able to teach students about symmetry when they cannot see it themselves.
Of the participants, $79 \%$ were able to build a structure with unit blocks using views of it from the right, left, front and back. Thus, the participants were successful at building a structure with unit blocks when they were shown diagrams of it.

The participants were not very successful at drawing the front-right view of the structure they built with unit blocks. Of the participants, 15 were unable to draw it at all, and 8 drew it incorrectly. These results are consistent with those of the study by Duatepe and Paksu (2013), which focused on the drawing skills of pre-service elementary school teachers, and asked them to draw two structures, one made of five identical unit blocks and one made of six identical unit blocks. The study results revealed that approximately one-third of the participants were unable to draw them at all, and only one-fourth of the participants could accurately draw the structure.

\section{Conclusion}

Other than pre-service teachers, studies conducted with teachers and students have indicated that the skills of drawing geometrical viewpoints and perspectival drawing, which are directly related to spatial reasoning, is a problematic field in general. Dogan, Temur and Tertemiz (2012) conducted an observational study of elementary school teachers' activities during lessons, and analyzed their thoughts about geometry pedagogy using van Hiele levels. The study results indicated that the teachers taught geometry classes using activities based on their experiences, but did not include enough drawing activities in the lessons (Duatepe \& Paksu, 2013). Yolcu and Kurtulus (2010) also conducted a similar study. They both used concrete materials (unit blocks) and computer applications to improve sixth grade students' spatial skills. They also 
had students do different activities such as building structures using unit blocks and drawing those structures on isometric paper depicting different views of them. The study results revealed that students improved their visualization skills by building structures with unit blocks and drawing them on isometric paper. These activities showed that geometrical drawing skills are very important for students, teachers and pre-service teachers.

The results of this study and the findings of similar studies suggest that teacher training programs should include activities that use concrete models to improve students' spatial skills and visualization abilities, and, in particular, drawing activities that use isometric paper to improve their drawing skills.

\section{References}

Clements, D.H. \& Battista, M.T. (1992). Geometry and spatial reasoning. In D. A. Grouws (Eds.), Handbook of research on mathematics teaching and learning (pp. 420-464). Don Mills, ON: Maxwell Macmillan.

Doğan-Temur, Ö. \& Tertemiz, N. (2012). İlköğretim birinci kademe ögretmenlerinin geometri öğretimine ilişkin sınıf içi uygulamalarının van Hiele seviyelerine göre irdelenmesi. DPUJSS, 32(2), 255-274.

Duatepe Paksu, A. (2013). Sınıf öğretmeni adaylarının geometrik yapılara ilişkin çizim becerilerinin incelenmesi. Kastamonu Ĕgitim Dergisi, 21(3), 827-840.

Hoffer, A. (1981). Geometry is more than proof. Mathematics Teacher, 74(1), 11-18.

Ministry of National Education [MoNE]. (2005). ilköğretim ders programları: Matematik programı 1-5 (Elementary curricula programs: mathematics curriculum program for 1-5 grades). Ankara, Turkey: MEB.

Ministry of National Education. [MoNE]. (2009). Ilköğretim matematik dersi öğretim programı. Retrieved from: http://ttkb.meb.gov.tr/www/ogretimprogramlari/icerik/72.

National Council of Teachers of Mathematics. (2000). Principles and standards for school Mathematics. Reston. VA.

Piaget, J., \& Inhelder, B. (1967). The child's conception of space. New York, NY: W. W.

Powel, M. J. (1997). Geometry, mathematics in the middle grades: Excerpts from NCTM standards. <http://www.sedl.org/ >. (2005.10.12).

Werthessen, H. (1999). Instruction in spatial skills and its effect on self-efficacy and achievement in mental rotation and spatial visualization (Doctoral Dissertation). Columbia University. <http://wwwlib. umi.com/dissertations/fullcit/9634439> (2015.03.24).

Van de Walle, J. A., Karp, K.S., \& Bay-Williams, J. M. (2009). Elementary and middle school mathematics: Teaching developmentally (7th Edition). Boston, USA: Allyn \& Bacon.
Yıldırım, A. \& Şimşek, H. (2011). Sosyal bilimlerde nitel araştırma yöntemi. Seçkin Yayıncılık. Ankara, Turkey.

Yolcu, B. \& Kurtuluş, A. (2010). 6. Sınıf öğrencilerinin uzamsal görselleştirme yeteneklerini geliştirme üzerine bir çalışma. Elementary Education Online, 9(1), 256-274. 